\title{
STUDENTS' PERCEPTIONS TOWARD LEARNING MATERIALS USED IN ONLINE LEARNING
}

\author{
Nuryansyah Adijaya ${ }^{1}$, Ratih Pertiwi ${ }^{2}$ \\ ${ }^{1}$ Esa Unggul University \\ ${ }^{1}$ nuryansyah@esaunggul.ac.id \\ ${ }^{2}$ Esa Unggul University \\ ${ }^{2}$ ratih@esaunggul.ac.id
}

\begin{abstract}
Online learning is assumed as a new paradigm in learning-teaching process in which lecturer and students do not need to sit in the same room to make class activities. They just need a gadget with internet connection to create the activities. Along with the practical of online learning, many institutions or universities in Indonesia create online learning to support learning-teaching process. However, online learning still faces some problems in learning activity, one of the problems is the use of learning materials. This study is aimed to explore students' perceptions toward the use of learning materials in online learning whether the learning materials already support their activity in online class. 100 students of online learning TOEFL 2 are targeted to be research data. They are given some questions to explore their perceptions related to their perceptions toward the use of learning material. Besides, some students are also interviewed to explore deeper information. Quantitative analysis is employed in the study. This study reveals that students cannot decide whether learning material used in online learning already support online class or not which shown by mean score that reaches 2,805. they think materials are practical. However, they sometimes face some difficulties of using the materials; to understand instruction, responses, etc.These factors make students cannot decide their perception toward the use of learning material in online learning. That is why to support online learning, we must periodically revise learning materials for online learning.
\end{abstract}

Keywords: online learning, students' perception, learning material

\section{INTRODUCTION}

Nowadays, Online learning has become a trending discussion in learningteaching process. it is assumed as a new paradigm and innovation in class activities because to hold a class, a lecturer and students do not need to sit in the same room to make the activities. They just need a gadget with internet connection to create a class. What they have to do is just log on to certain site and class activities are ready for them. That is why many institutions and universities in Indonesia and also around the world create online class to support learning-teaching process. However, in reality, online learning faces some problems in class process. Jacobs (2013) stated students' interaction, learning environment, technology support, and learning material are common obstacle occur in online learning. This explanation gives an implicit message or alarm that online learning needs to be improved, especially learning materials. Learning material is one of important things in learning-teaching process. It should support students' learning process. But why it becomes a problem in online learning? This situation inspires researchers to conduct a research to explore students' perceptions toward learning material used in online class. 


\section{LITERATURE REVIEW}

\subsection{Online learning}

Online learning or virtual learning is a kind of studying activity which relies class activities on internet connection. Kucirkova et al (2012) and Kanninen (2009) define online learning as a high-tech learning in which a class can be created everywhere by using internet connection. Internet connection in here means a set of gadget or electronic devices which has certain program and it is connected to internet connection. Therefore, lecturer and teachers can access and open the class. The definition can be concluded that all activities; students' interaction, giving and explaining material, assessing, etc in online learning is relied on internet connection.

\subsection{Obstacles in Online Learning}

Online learning has become a new phenomena in learning process as a hightech leaning teaching process in which class activity is relied on electronic devices and internet connection. However, online learning is not a perfect learning-teaching process that can run without obstacles. Fortune et al (2011) and Ellis et al (2009)stated that there are several obstacles found in online learning; learning achievement, students' interaction, and learning material. This fact implicitly gives us a message that we should find a solution for the obstacles to improve quality of online learning. For example, if learning material becomes an obstacle in learningteaching process, it can influence students' learning achievement. Thus, to help students get better learning achievement, the obstacles in online learning should be anticipated.

\subsection{Learning Material}

Learning material has important role in learning-teaching activity. Learning material is everything used by lecturer and students to facilitate their learningteaching process which contains instruction, samples, etc. Besides, learning material also must be able to help students get experiences in learning process. Tomlinson (1998) and Mc Grath (2013) define learning materials as everything which can be used to help lecturer and students in leaning process that contains learning instructions, samples, topic materials, assessment, and learning achievement which is intended to help students get learning learning experiences.

\subsection{Students' perception}

Students' perception is students' point of view or response toward certain phenomena or everything that happens in learning-teaching process; learning process, learning material, student's needs, etc. Struyven (2005) defines students' perception as a set of concepts used to identify ideas, beliefs, opinions, pictures, and students' needs about education and its activities. Based on the information about students' perception, it can be concluded that students' perception is information collected from students related to phenomena in learning-teaching process

\section{METHODS}

This study is aimed to analyze students' perception related to the use of learning material in online learning TOEFL 2. The students are given a questionnaire that used Likert scale to explore their perception about learning material used in their class. Boone and Boone (2012) explained that likert scale agree-disagree or satisfy-dissatisfy to measure measure people's opinions, behaviors, etc toward certain phenomena. Besides questionnaire, some students are also interviewed to strengthen the data on the questionnaire. Therefore, research 
method used in this research is survey. Cresswell (2012) stated that survey is a method used in quantitative research to collect in form of behaviors, characteristics, opinions, etc from certain population. Based on the definition about quantitative survey research, it can be concluded that the method is appropriate to be used in this research that analyzes students' perceptions.

Negative

Neutral

Positive

Disagree

strongly (1)
Disagree

(2)

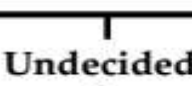

(3)
Agree

strongly (5)

Figure 1: Likert Scale

\section{FINDINGS AND DISCUSSION}

Based on the data have been analyzed, researchers found that students cannot decide whether learning material already support their learning process in online class which means that the students are neutral in giving their perception. The data is shown in the table below.

\begin{tabular}{|c|c|c|c|c|c|c|c|c|}
\hline \multirow[b]{2}{*}{ No } & \multirow[b]{2}{*}{ Questions } & \multicolumn{5}{|c|}{ Scale } & \multirow[b]{2}{*}{ Mean } & \multirow[b]{2}{*}{ Category } \\
\hline & & $\begin{array}{l}\text { Strongly } \\
\text { disagree }\end{array}$ & Disagree & Undecided & Agree & $\begin{array}{c}\text { Strongly } \\
\text { agree }\end{array}$ & & \\
\hline 1 & $\begin{array}{l}\text { Learning process is } \\
\text { more effective in online } \\
\text { class than in face-to- } \\
\text { face class }\end{array}$ & 11 & 33 & 32 & 17 & 7 & 2.76 & undecided \\
\hline 2 & $\begin{array}{l}\text { To understand learning } \\
\text { material is easier in } \\
\text { online class than face- } \\
\text { to-face class. }\end{array}$ & 15 & 32 & 29 & 21 & 3 & 2.64 & Undecided \\
\hline 3 & $\begin{array}{l}\text { Lecturer's response or } \\
\text { server already satisfy or } \\
\text { help students to } \\
\text { understand learning } \\
\text { materials }\end{array}$ & 5 & 34 & 27 & 26 & 8 & 2.98 & Undecided \\
\hline 4 & $\begin{array}{l}\text { Learning instruction is } \\
\text { easier to understand in } \\
\text { online class than in } \\
\text { face-to-face class. }\end{array}$ & 11 & 35 & 29 & 23 & 2 & 2.69 & Undecided \\
\hline 5 & $\begin{array}{l}\text { If students face } \\
\text { problems to understand } \\
\text { materials given, it is } \\
\text { easier to solve them in } \\
\text { online class than in } \\
\text { face-to-face class }\end{array}$ & 17 & 34 & 29 & 16 & 4 & 2.56 & Disagree \\
\hline 6 & $\begin{array}{l}\text { To answer exercises or } \\
\text { questions given, it is } \\
\text { easier in online class } \\
\text { than in face-to-face } \\
\text { class }\end{array}$ & 7 & 32 & 26 & 24 & 11 & 3 & Undecided \\
\hline 7 & $\begin{array}{l}\text { Online learning is } \\
\text { designed to make } \\
\text { students easier to } \\
\text { understand learning } \\
\text { material }\end{array}$ & 9 & 32 & 27 & 22 & 10 & 2.92 & Undecided \\
\hline 8 & $\begin{array}{l}\text { Learning materials } \\
\text { which is given in online } \\
\text { learning already support } \\
\text { students in learning } \\
\text { process }\end{array}$ & 7 & 32 & 27 & 29 & 5 & 2.93 & Undecided \\
\hline
\end{tabular}




\begin{tabular}{|l|l|c|c|c|c|c|c|c|}
\hline \multirow{2}{*}{ No } & \multicolumn{1}{|c|}{ Questions } & $\begin{array}{l}\text { Strongly } \\
\text { disagree }\end{array}$ & Disagree & Undecided & Agree & $\begin{array}{c}\text { Strongly } \\
\text { agree }\end{array}$ & Mean & Category \\
\hline 9 & $\begin{array}{l}\text { Learning materials used } \\
\text { in online class make } \\
\text { students more confident } \\
\text { to face examination }\end{array}$ & 6 & 39 & 35 & 18 & 2 & 2.71 & Undecided \\
\hline 10 & $\begin{array}{l}\text { I think, all subjects } \\
\text { should be held in online } \\
\text { learning }\end{array}$ & 9 & 24 & 47 & 12 & 8 & 2.86 & Undecided \\
\hline
\end{tabular}

The data above is converted into score range to find mean score as shown in the table below.

$\mathrm{RS}=(\mathrm{m}-\mathrm{n}) / \mathrm{b}$

$\mathrm{RS}=(5-1) / 5$

$\mathrm{RS}=0.8$

$\mathrm{SR}=$ Score Range

$\mathrm{m}=$ the highest score

$\mathrm{n}=$ the lowest score

$b=$ number of category

\begin{tabular}{|l|l|}
\hline Score range & Level of agreement \\
\hline $1 \leq \mathrm{X}<1.8$ & Strongly disagree \\
\hline $1.8 \leq \mathrm{X}<2.6$ & disagree \\
\hline $2.6 \leq \mathrm{X}<3.4$ & Undecided \\
\hline $3.4 \leq \mathrm{X}<4.2$ & Agree \\
\hline $4.2 \leq \mathrm{X}<5$ & Strongly agree \\
\hline
\end{tabular}

After converting the data, researchers found that score range of students perception reaches 2.805 which means students cannot decided or neutral toward the use of learning materials in their online learning class. According to data from interview reveals that students cannot decide because they think that leaning material used in online learning is practical. However, they often face difficulties to use learning material in online class; to understand learning instruction, to find solution if they do not understand certain materials, etc.

\section{CONCLUSION}

Based on the findings of the research, students are neutral or they cannot decide about the use of learning material used in online learning which shown by mean score that reaches 2.805. According to the result of students interview, it reveals that they are neutral or cannot decide because the learning materials have strengths and weakness in online learning. In other side, the use of learning materials in online learning is very practical. The students can use or read the materials everywhere. However, the students sometimes face some difficulties to use learning material in online class; understand learning instruction, find solution if they have problems to understand materials, etc. Therefore, to help students get better learning achievement, It needs to do some revisions for learning material used in online learning. 


\section{REFERENCES}

Boone Jr, H.N., Deborah,A.Boone. (2012). Analyzing Likert Data. Journal Of Extension, Vol.50, No.2.

Cresell, J.W. (2012). Planning, Conducting, and Evaluating Quantitative and Qualitative Research $\left(4^{\text {th }}\right.$ ed). Boston: Pearson Education Inc.

Ellis, R.A., Paul Ginns., and Leanne, P. (2009). E-learning in Higher Education: Some Key Aspects and the Their Relationship to Approaches to Study. Higher Education Research and Development Vol. 28, No. 3(pp303-318).

Fortune, M.F., Melany, S., and Pangelinan, D.T. (2011). Students' perceptions of Online or Face-to-Face Learning and Social Media in Hospitality, Recreation and Tourism. MERLOT Jornal of Online Learning and Teaching Vol. 7, No. 1.

Jacobs,Pearl.(2013). The challenges of online courses for the instructor. Research in Higher Education Journal, Vol (21). taken fromhttp://www.aabri.com/manuscripts/131555.pdf

Kanninen, Essi. (2009). Learning Styles and E-Learning. Taken from https://lehre-svn.emsp.tuberlin.de/Evicab/outcomes/delivera/wp4style.pdf

Kucirkova, L., Petr, K., and Hana, V.V. (2012). Study Result and Questiosnaire Survey of Students in the Lesson of Business English ELearning Course in Comparison With Face-To-Face Teaching. Journal on Efficiency and Responsibility in Education and Science, Vol. 5 No. 3 (pp 173-184).

McGrath, Ian. (2008). Materials Evaluation and Design for Language Teaching. Edinbergh: Edinbergh University Press.

Struyven, K., Filip, D. and Steven, J. (2005). Students' Perceptions about Evaluation and Assessment in Higher Education: Review. Assessment \& Evaluation in Higher Education, Vol. 30, No. 4(pp331-347).

Tomlinson, Brian. (1998). Material Development in Language Teaching. Cmbridege: Cambridge University Press. 